\title{
CITRA KOTA SEBAGAI STRATEGI PENGEMBANGAN PARIWISATA KOTA JUWANA
}

\author{
Theresia Budi Jayanti \\ Jurusan Teknik Arsitektur, Universitas Tarumanagara Jakarta \\ Email: theresia.bj@gmail.com
}

\begin{abstract}
ABSTRAK
Juwana merupakan sebuah kecamatan di Kabupaten Pati, Jawa Tengah. Kota Juwana berada di jalur utama Pantura (Pantai Utara Jawa) menghubungkan Kota Pati dan Kota Rembang. Posisi ini dinilai strategis karena menghubungkan jalur mobilitas, transportasi serta perekonomian di wilayah Jawa sebelah Timur (Surabaya) dengan wilayah Jawa sebelah Barat (Jakarta) dan Tengah (Semarang). Disamping hal tersebut diatas, komoditas unggulan seperti hasil tangkapan ikan dari laut dan pengolahannya juga dimiliki Juwana. Industri kuningan juga merupakan faktor penggerak perekonomian di Kota Juwana. Potensi-potensi tersebut diatas tidak didukung dengan adanya identitas kota yang jelas, sehingga citra kota Juwana sebagai salah satu destinasi wisata dirasa belum kuat. Tujuan dari penelitian ini adalah untuk mengetahui citra kota Juwana sehingga dapat digunakan sebagai strategi pengembangan wisata Kota Juwana. Metode yang digunakan dalam penelitian ini adalah strategy grounded theoryresearch. Pembahasan dilakukan melalui analisis potensi fisik maupun non fisik, serta analisis elemen pembentuk citra kota Juwana. Hasil yang didapat berupa citra Kota Juwana sebagai heritage city;untuk kemudian dapat digunakan sebagai strategi pengembangan Kota Juwana.
\end{abstract}

Kata kunci: citra kota, strategi, wisata, juwana

\section{PENDAHULUAN}

Sektor pariwisata merupakan salah satu faktor penting dan dapat dijadikan prioritas dalam menunjang pembangunan suatu wilayah di Indonesia. Sebagai negara kepulauan terbesar; pengembangan sektor wisata di Indonesia bisa dilakukan dengan memanfaatkan daya tarik wisata yang berupa keindahan alam, keragaman flora dan fauna, kebudayaan, peninggalan sejarah maupun kehidupan masyarakat. Dewasa ini, Program-program pemerintah Indonesia dalam mengembangkan sektor pariwisata melalui pembenahan objek wisata dan faktor pendukung wisata lainnya(fasilitas, infrastruktur, dll) sudah mengalami kemajuan yang cukup baik. Potensi-potensi wisata tiap daerah atau kota mulai ditingkatkan, sehingga setiap kota mempunyai identitas masingmasing sehingga dapat memperkuat citra suatu kota.

Citra Kota merupakan kesan fisik yang memberikan ciri khas kepada suatu kota. Citra kota berperan sebagai pembentuk indentitas serta penambah daya tarik di dalam pengembangan sebuah kota. Oleh karena itu, citra kota yang jelas dan kuat akan memperkuat identitas dan wajah kota sehingga membuat kota tersebut menarik dan memiliki daya tarik. Citra dan identitas kawasan seakan telah menjadi tolak ukur bagi kualitas suatu lingkungan khususnya menyangkut cara pandang orang terhadap nilai lingkungan tersebut (Purwanto, 2014).

Dalam buku The Image of The City (Lynch, 1960), citra terhadap suatu lingkungan kota dapatdipahami melalui 3 komponen dibawah ini:

- Identitas; identitas pada sebuah objek pada suatu kota yang khas atau berkarakter yang berbeda dengan yang lain. Identitas kota pada hakekatnya merupakan jejak peradaban yang ditampilkan sejarah suatu kota (Budihardjo, 2009).

- Struktur; atau pola saling berhubungan antara objek yang satu dengan yang lainnya dalam suatu ruang kota, sehingga fungsi kota dari objek tersebut berada dapat mudah dipahami.

- Objek tersebut mempunyai makna bagi pengamatnya terhadap kedua komponen diatas (identitas dan struktur) berdasarkan: keunikan, emosional, budaya, politik, simbolik dan historik. 
Dalam bukunya Image of The City, Kevin Lynch mengungkapkan ada 5 elemen pembentuk citra kota secara fisik, yaitu: path (jalur), edge (tepian), district (kawasan), nodes (simpul), dan landmark (penanda) (Lynch, 1960). Kelima elemen pembentuk tersebut dapat mewakili cita rasa dari suatu kawasan dan memberikan citra yang kuat terhadap kota. Selanjutnya menurut Lynch, kelima komponen tersebut mempunyai fungsi dan peran yang sangat penting sebagai satu kesatuan yang holistik dalam membentuk citra lingkungan kota (Purwanto, 2014).

Pederson (2002, dalam Southall dan Robinson,2011) menyatakan: "heritage tourism as embracing both eco-tourism and cultural tourism, with an emphasis on conservation and cultural heritage".Pernyataan tersebut bermaksud bahwa wisata warisan budaya dapat merangkul ekowisata dan wisata budaya pada saat bersamaan dan menitikberatkan kepada konservasi dan warisan budaya itu sendiri. Pengembangan wisata warisan budaya di perkotaan sangat ideal dilaksanakan karena suatu kota tidak akan kehilangan identitas lokal, serta memberikan pemahaman dan rasa kebanggaan terhadap sejarah kota dan kebudayaan lokal masyarakat setempat (Widayanti, 2015).

Juwana merupakan sebuah kecamatan di Kabupaten Pati, Jawa Tengah yang terdisi dari 29 desa (87 RT dan 62 RW).Secara geografis, Juwana terletak $12 \mathrm{~km}$ dari Pati yang merupakan ibukota Kabupaten Pati dan $87 \mathrm{~km}$ dari Semarang yang merupakan ibukota Provinsi Jawa Tengah. Kota Juwana berada di jalur utama Pantura atau Pantai Utara Jawa (dahulunya adalah jalur Deandels) yang menghubungkan Kota Pati dan Kota Rembang melalui Jalan Raya Juwana-Pati (lihat gambar 1). Posisi ini dinilai strategis karena menghubungkan jalur mobilitas, transportasi serta perekonomian di wilayah Jawa sebelah Timur (Surabaya) dengan wilayah Jawa sebelah Barat (Jakarta) dan Tengah (Semarang).Ga mbar 1 di bawah ini juga menunjukkan potensi pariwisata history/sejarah karena terdapat Objek Wisata Pulau Seprapat, Makam Datuk Ludang dan Makam Ki Ageng Ngerang.

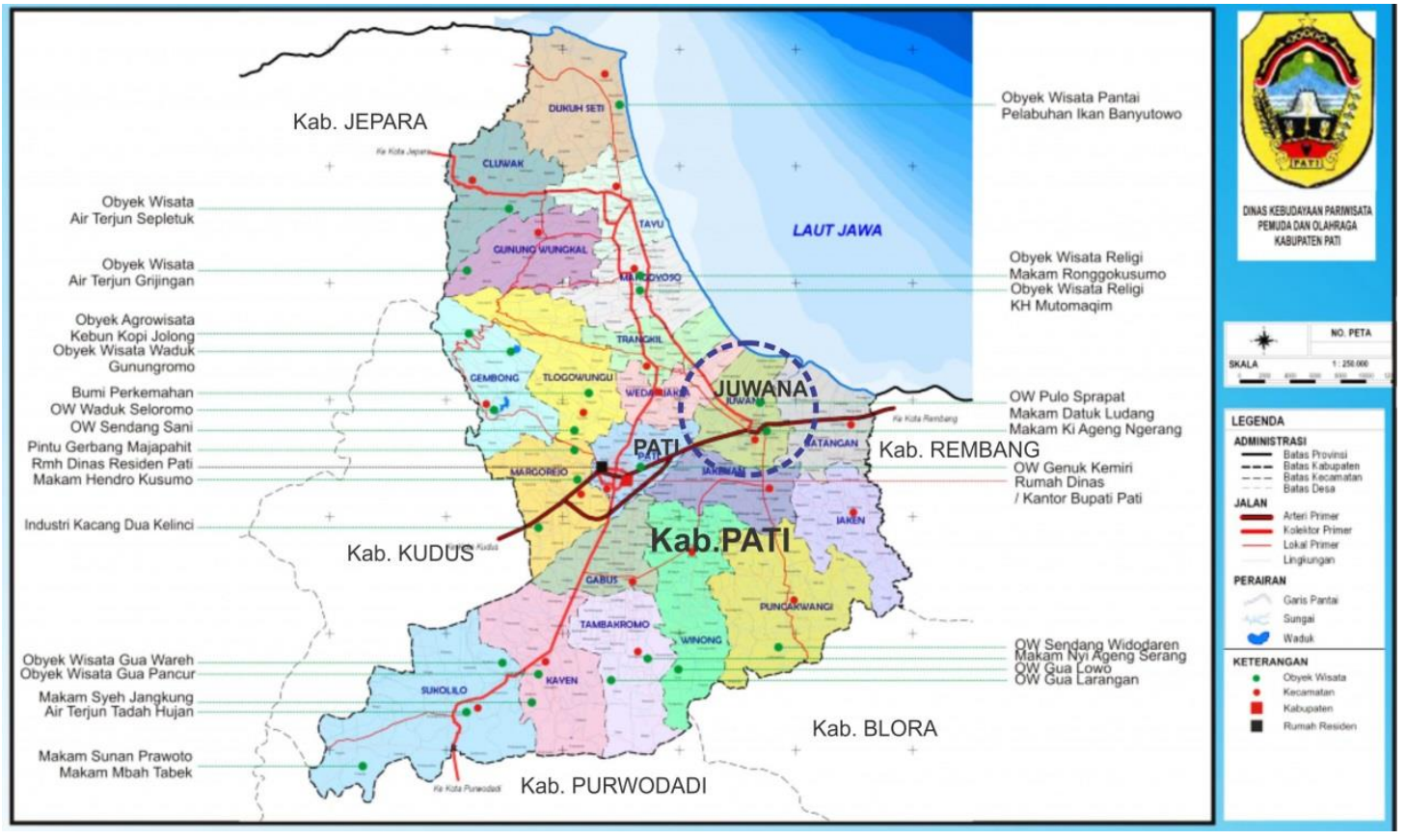

Gambar 1. Peta Posisi Juwana terhadap Kabupaten Pati Sumber: Dinas Kebudayaan dan Pariwisata Kabupaten Pati

Batasan administrasi Kota Juwana adalah sebagai berikut: sebelah utara dibatasi Laut Jawa, sebelah timur dibatasi Kecamatan Batangan, sebelah barat dibatasi Kecamatan Pati, serta 
Kecamatan Jakenan di sebelah selatan. Kota Juwana dilalui oleh Sungai Juwana (Silugonggo) yang menjadi daerah aliran Sungai Waduk Kedungombo, sungai tebesar di Kabupaten Pati tersebut mengakibatkan banjir setiap tahunnya. Disamping hal tersebut, Sungai Silugonggo juga mempunyai peranan penting karena terdapat Pelabuhan Juwana dan menghubungkan dengan Laut Jawa (lihat gambar 2). Penduduk Juwana mayoritas memiliki mata pencaharian bidang pertanian, buruh dan sebagai nelayan.

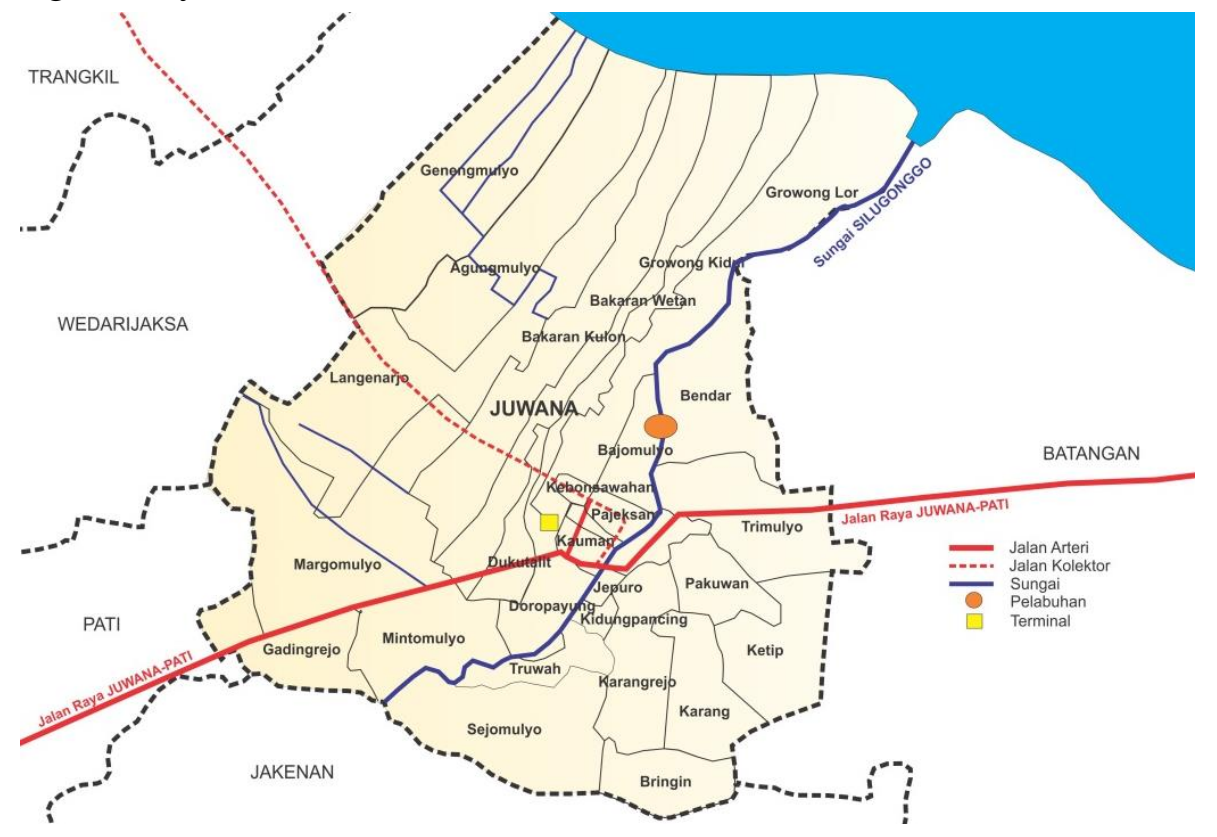

Gambar 2. Pembagian wilayah desa di Juwana Sumber: Olahan Penulis, 2017

Juwana juga mempunyai komoditas unggulan seperti hasil tangkapan ikan dari laut dan pengolahannya, terutama ikan bandeng. Usaha tambak perikanan banyak terdapat di Desa Bajomulyo dan Desa Agungmulyo. Industri kuningan juga merupakan faktor penggerak perekonomian di Kota Juwana. Sebagian besar logam kerajinan logam kuningan terdapat di Desa Growong dan sekitarnya. Di Kota Juwana juga terdapat cabang dari parik rokok Djarum dan Tapal Kuda (salah satu pabrik rokok tertua di Indonesia). Selain hal tersebut, Pelabuhan Juwana juga menjadi akses perekonomian sekaligus akses utama untuk keluar masuk kapal dari Kalimantan yang membawa kayu. Beragam komoditas yang ada tersebut di jual diluar Kota Juwana, misalnya Semarang, Yogyakarta, Surabaya dan Jakarta. Hal tersebut berakibat aktivitas perdagangan dengan komoditi asli Juwana, belum bisa mengangkat nama Kota Juwana. Sebagai salah satu contoh adalah bandeng. Penjualan bandeng tersebut mayoritas dilakukan di Semarang, sehingga mayoritas wisatawan lebih mengenal Semarang sebagai penghasil bandeng daripada Juwana, walaupun sudah ada upaya branding nama bandeng Juwana pada kemasan produknya.

Pada kenyataannya potensi-potensi Kota Juwana yang ada tidak didukung dengan citra kota yang jelas, sehinggacitra kota Juwana dirasa belum dirasa kuat untuk menjadi salah satu destinasi wisata di Jawa Tengah. Citra Kota Juwana diharapkan nantinya akan menjadi salah satu strategi dalam mengembangkan pariwisata kota Juwana.

\section{METODE PENELITIAN}

Penelitian ini berlokasi di Juwana, Kabupaten Pati, Jawa Tengah. Tujuan dari penelitian ini adalah untuk mengetahui citra kota Juwana sehingga dapat digunakan sebagai strategi pengembangan 
wisata Kota Juwana. Penelitian ini menggunakan metode kualitiatif dengan menggunakan desain grounded theory research. Beberapa definisi mengenai grounded theory antara lain:

Grounded theory is a methodology that seeks to construct theory about issues of importance

in peoples' lives (Strauss \& Corbin, 1998).

GT is a research method that prescribes systematic guidelines for data collection and analysis with the purpose of inductively building a framework explaining the collected data (Charmaz, 2000 dalam Sudira, 2009)

GT is an inductive theory discovery methodology that allow researcher to develop atheoritical account of the general features of the topics while simultaneously grounding account in empirical observations of data (Martin \& Tuner, 1986 dalam Sudira 2009)

Dari beberapa definisi di atas dapat disimpulkan bahwa grounded theory adalah sebuah metodologi penelitian kualitatif yang menekankan penemuan teori dari observasi dan sejumlah data yang ada; kemudian menganalisis melalui kategorisasi serta merekonstruksi penafsiran dan pemaknaan hasil penelitian berdasarkan konseptualisasi masyarakat yang ada di objek studi.

Pengumpulan data dilakukan melalui data primer dan data sekunder. Data primer didapat dengan cara melakukan pengamatan langsung terhadap wilayah atau desa di Kota Juwana, melakukan pendataan, dokumentasi serta melakukan investigasi. Data sekunder diperoleh melalui studi literatur melalui buku, jurnal, prosiding maupun data internet yang relevan. Data primer dan sekunder kemudian diolah sehingga didapatkan temuan-temuan. Temuan tersebut dianalisis untuk menemukan citra kota Juwana sehingga kemudian dapat dilakukan strategi dalam pengembangan sektor wisatanya.

\section{HASIL DAN PEMBAHASAN}

Suatu kota harus mempunyai karakter atau sesuatu yang khas supaya dapat dipahami citranya dengan mudah. Karakter kota diperlukan untuk memberikan pernahanan tentang identitas kota, sesuai dengan potensi yang ada. Dalam hal ini, karakter merupakan jiwa, perwujudan watak, baik secara fisik maupun non-fisik, yang memberikan suatu citra dan identitas kota (Lynch dalam Purwanto, 2014). Untuk mengetahui citra kota dari Kota Juwana, maka dilakukan identifikasi potensi Kota Juwana (fisik dan non fisik) serta elemen pembentuk citra Kota Juwana (landmark, path, district, nodes, edge). Potensi wisata adalah semua objek (baik berupa alam, budaya, buatan) yang memerlukan penanganan yang baik agar dapat memberikan nilai daya tarik bagi wisatawan (Damanik \& Weber, 2006).

\section{POTENSI FISIK KAWASAN KOTA:}

\section{a. Lokasi}

Letak Kecamatan Juwana yang berada di Jalan Pantura (jalan utama Pantai Utara Jawa) merupakan posisi yang strategis karena menghubungkan jalur mobilitas, perekonomian serta transportasidi wilayah Jawa Timur (Surabaya dan Bali) dengan wilayah Jawa sebelah Barat dan Tengah (Banten, Jakarta, dan Semarang). Posisi yang strategis ini memberikan keuntungan berupa kemudahan dalam distribusi barang dan jasa serta perpindahan manusia, terutama yang menunjang pengelolaan sumber daya pesisir (lihat pada gambar 1).

\section{b. Bangunan}

Kota Juwana memiliki bangunan bersejarah dengan ciri khas arsitektur Kolonial Belanda, Cina dan Jawa. Bangunan kuno dengan ciri arsitektur Jawa mayoritas berada di Desa Bakaran Kulon dan Wetan, Desa Bringin. Bangunan kuno dengan ciri arsitektur Belanda berada di Desa Kauman dan Doropayung; sedangkan bangunan berarsitektur Cuna berada di DesaTruwah, Jepuro, Pajeksan, Kebonsawahan, Bajomulyo dan Desa Bendar.Mayoritas bangunan 
bersejarah di Juwana termasuk dalam Lingkungan Cagar Budaya Golongan 2. Penggolongan tersebut dimaksudkan bahwa penataan lingkungan atau bangunan harus tetap mempertahankan keaslian unsur unsur lingkungan serta arsitektur yang menjadi ciri khas daerah tersebut.Peninggalan sejarah seperti bangunan dengan gaya arsitektur tersebut dapat dijadikan obyek wisata potensial, dengan mempertimbangkan pelestarian keaslian bangunan.
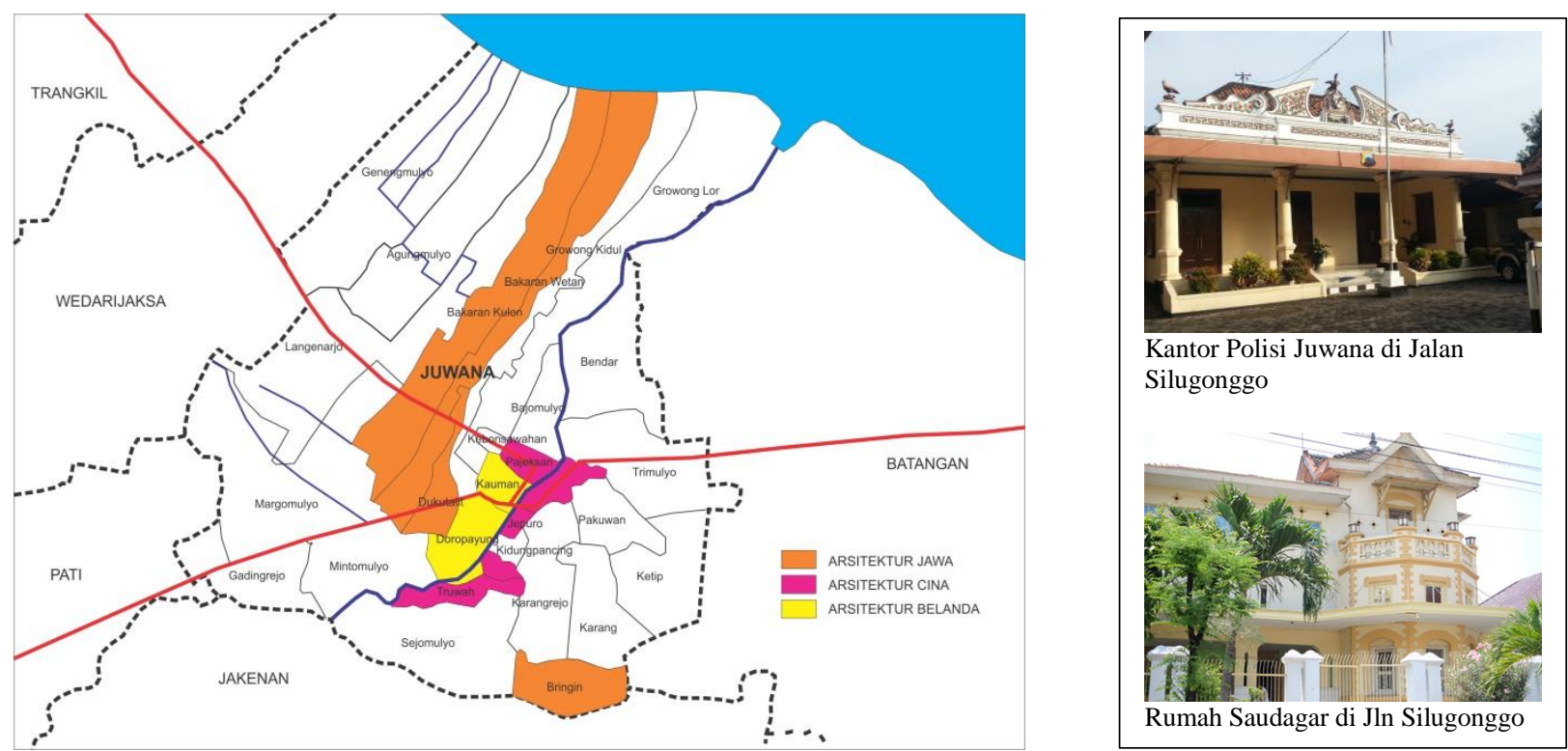

Gambar 3. Persebaran bangunan berlanggam Jawa, Cina dan Kolonial Sumber: Olahan penulis, 2017

\section{c. Infrastruktur}

Letak Kota Juwana yang berbatasan langsung dengan laut dapat mendukung potensi pelabuhan Juwana dalam kegiatan transportasi barang melalui laut.

Juwana dilalui oleh jalan arteri primer (Jalan Jend. Sudirman / Jalan Raya Juwana-Pati) yang merupakan jalur regional yang membagi Juwana menjadi dua bagian, yaitu sebelah utara dan sebelah selatan kota, dan menjadi sumbu utama pergerakan regional dan lokal di Juwana, sehingga hal tersebut menjadi potensi dalam perkembangan Kota Juwana nantinya.

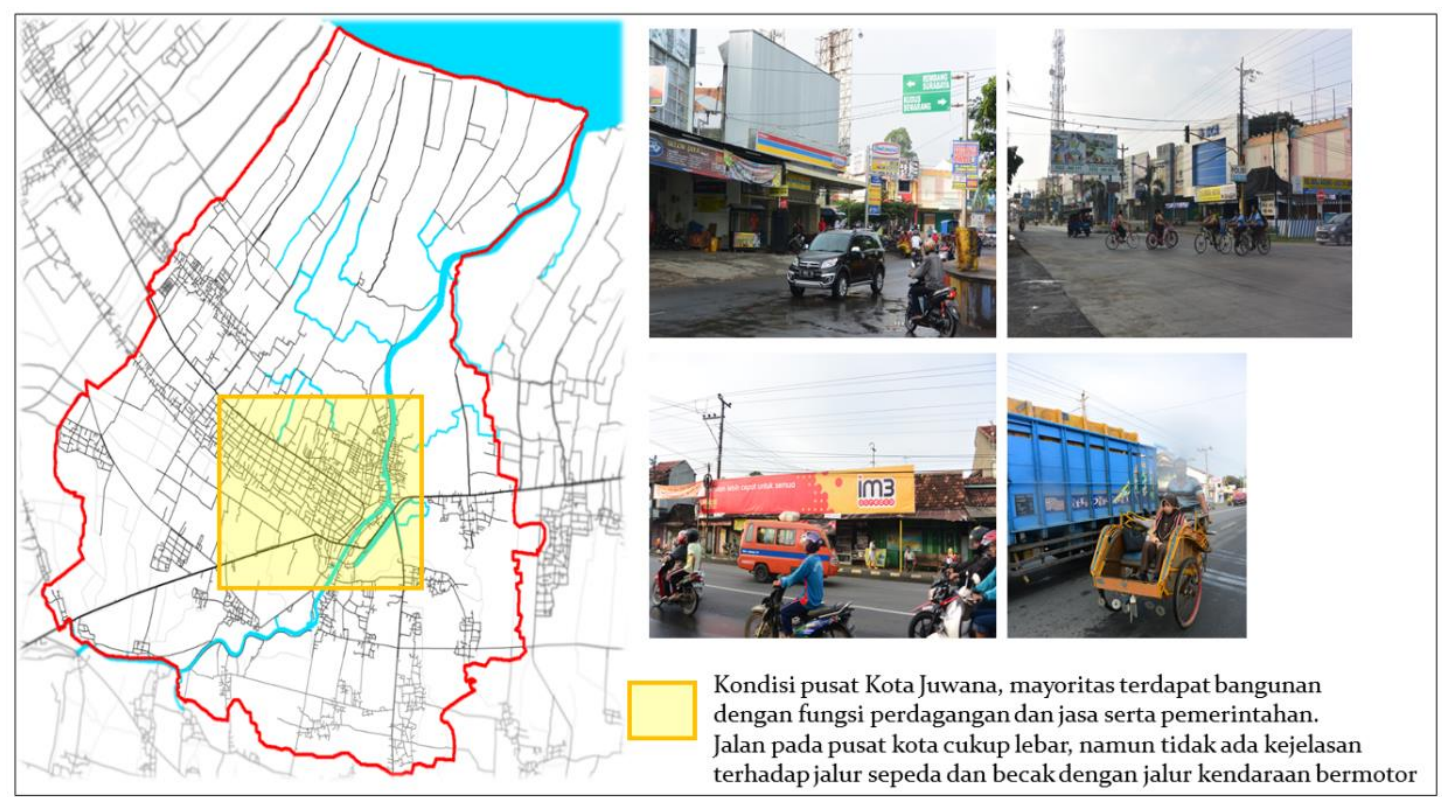


Gambar 4. Kondisi Infrastrukstur Pusat Kota Juwana

Sumber: Olahan penulis, 2017

Pola jaringan Kota Juwana memusat pada daerah pusat kotanya (desa Kauman). Berdasarkan hal tersebut, kota ini dapat berfungsi sebagai simpul distribusi karena berada pada simpul jalur transportasi yaitu pertemuan jalur transportasi Jakarta dengan Surabaya, selain itu, Juwana juga daerah yang strategis karena memiliki pelabuhan. Keuntungan yang dimiliki adalah mudah untuk memusatkan kegiatan kota dan efektif dalam pergerakan. Struktur ini mempengaruhi pemusatan aktivitas sehingga memungkinkan pusat aktivitas yang terkonsentrasi pada satu pusat saja, yaitu di sekitar alun-alun Kota Juwana (termasuk kedalam wilayah Desa Kauman).

Aspek ketersediaan sarana angkutan di Juwana, untuk angkutan dilayani oleh mini bus, angkutan kota, becak, ojek, dan dokar (angkutan tradisional menggunakan kuda), sedangkan angkutan barang dilayani oleh mobil pick up dan truk. Alur trayek angkutan hanya berlaku untuk angkutan manusia, sedangkan angkutan barang tidak diatur dalam trayek tertentu, tetapi harus memperhatikan kelas jalannya.

\section{POTENSI NON FISIK}

\section{a. Ekonomi}

Tabel 1. Potensi Ekonomi Kota Juwana

\begin{tabular}{|c|l|}
\hline \multirow{5}{*}{ Kuningan } & $\begin{array}{l}\text { Industri kerajinan kuningan di Juwana dimulai sejak pada jaman Deandels. } \\
\text { Pada mulanya, pusat industri kerajinan kuningan Juwana dipusatkan di Desa } \\
\text { Pajeksan lalu bergeser ke ke Desa Kudukeras dan bergeser lagi ke Desa } \\
\text { Growong (Growong Lor dan Kidul). Di Desa Growong inilah diproduksi } \\
\text { beragam barang kebutuhan rumah tangga dan barang antik seperti peralatan } \\
\text { kompor gas, peralatan kompresor, peralatan pompa air, souvenir, handle } \\
\text { pintu, lampu antik dan lain sebagainya. Produk kerajinan tersebut, terutama } \\
\text { yang berupa barang-barang antik, sudah didistribusikan ke seluruh } \\
\text { Indonesia dan bahkan menjadi komoditas ekspor ke mancanegara. }\end{array}$ \\
\hline Batik Bakaran \\
$\begin{array}{l}\text { Kakaran (Bakaran Wetan dan Bakaran Kulon) merupakan desa yang ada di } \\
\text { mecamatan Juwana, Kabupaten Pati. Kedua desa Bakaran ini juga } \\
\text { yaitu batik tulis. Corak atau motif batik Bakaran sangat unik dan khas, yang } \\
\text { berbeda dengan motif/corak batik-batik lainnya di Pulau Jawa walaupun } \\
\text { berasal dari budaya yang sama yaitu keraton. Kekhasan motif/corak tersebut } \\
\text { terjadi karena adanya perpaduan antara kebudayaan pedalaman (tengahan) } \\
\text { dengan pesisir. Dengan kata lain, motif/corak Batik Bakaran pada umunya } \\
\text { berdasarkan filosofis yang bersumber dari kerajaan Majapahit (wilayah } \\
\text { pedalaman) serta berdasarkan geografis (budaya pesisir). Warna yang } \\
\text { mendominasi batik Bakaran (khususnya Bakaran Wetan) adalah hitam dan } \\
\text { coklat. }\end{array}$ \\
$\begin{array}{l}\text { Hasil penangkapan ikan dan hasil tambak yang melimpah di Juwana } \\
\text { membuat masyarakatnya berpikir secara aktif dalam mengolah hasil } \\
\text { tangkapannya. Hasil nelayan dan tambak Juwana daiantaranya adalah ikan } \\
\text { bandeng, ikan pindang dan udang. Hasil tersebut kemudian diolah menjadi } \\
\text { beraneka macam produk olahan untuk menambah nilai jual serta } \\
\text { meningkatkan pendapatan masyarakatnya. Produk olahan yang dimaksud } \\
\text { seperti produk ikan bandeng (presto, tanpa duri, otak-otak, kerupuk, dll.) }\end{array}$ \\
\hline Pengolahan \\
Ikan
\end{tabular}




\begin{tabular}{|c|c|}
\hline & $\begin{array}{l}\text { au produk olahan ikan pindang (direbus, diasinkan, diasap, dan } \\
\text { keringkan). }\end{array}$ \\
\hline $\begin{array}{l}\text { Bumbu } \\
\text { Rumah } \\
\text { Tangga } \\
\text { (Terasi, } \\
\text { Kecap, } \\
\text { Garam) }\end{array}$ & $\begin{array}{l}\text { Terasi sudah di produksi oleh masyarakat sejak dulu, hal ini karena Juwana } \\
\text { adalah daerah pesisir dengan penghasil ikan yang banyak yang merupakan } \\
\text { salah satunya bahan-bahan terasi. Produksi terasi Juwana merupakan } \\
\text { industri rumahan, dan mayoritas di buat secara manual dan asli tanpa bahan } \\
\text { campuran. Selain terasi, industri rumahan lainnya ada kecap. Kecap yang } \\
\text { terkenal di Kota Juwa adalah kecap Cap Gentong, dengan rumah } \\
\text { produksinya terletak di Jalan Silugonggo, Kauman atau di sekitar alun-alun } \\
\text { Juwana. } \\
\text { Posisi Juwana yang berbatasan langsung dengan laut membuat Juwana } \\
\text { termasuk dalam } 4 \text { kecamatan di wilayah Pati sebagai penghasil garam } \\
\text { terbesar (termasuk lainnya adalah kecamatan Batangan, Juwana, } \\
\text { Wedarijaksa dan Trangkil). Desa penghasi garam di wilayah Juwana adalah } \\
\text { Desa Langgenharjo, Desa Trimulyo dan Desa Agungmulyo. Disamping } \\
\text { budidaya bandeng dan udang,pembuatan garam di tambak merupakan salah } \\
\text { satu alternatif usaha yang mempunyai nilai ekonomis yang cukup } \\
\text { tinggi.usaha pembuatan garam biasanya dilakukan masyarakat pada musim } \\
\text { kemarau, sekitar April - Oktober. }\end{array}$ \\
\hline $\begin{array}{l}\text { Perlengkapan } \\
\text { Nelayan }\end{array}$ & $\begin{array}{l}\text { Industri penangkapan ikan tidak bisa terlepas dari perlengkapan nelayan } \\
\text { ketika menangkap ikan. Desa Bendar, Desa Bumirejo dan Desa } \\
\text { Kedungpancing merupakan desa di Kota Juwana yang mempunyai usaha } \\
\text { perlengkapan nelayan seperti galangan kapal dan jaring. Desa Bendar } \\
\text { terutama, merupakan desa yang mayoritas penduduknya sukses sebagai } \\
\text { nelayan sekaligus pengusaha kapal. Produksi kapal kayu lokal Juwana juga } \\
\text { sudah di ekspor ke berberapa negara di Asia dan Eropa.Jenis kapal yang ada } \\
\text { di desa Bendar diantaranya adalah kapal cantrang, kapal penampung, kapal } \\
\text { holler atau pancing, kapal cumi, kapal cakalan, kapal kursin manual, dan } \\
\text { yang terbaru ada kapal kursin freezer. }\end{array}$ \\
\hline
\end{tabular}

Sumber: Penulis, 2017

\section{b. Sosial dan Budaya}

Potensi budaya seperti dalam bidang kesenian dan kebudayaan di miliki Juwana secara turun menurun. Kesenian yang ada di Juwana adalah kesenian kethoprak, kesenian kenthrung, kesenian laesan, dan kesenian rebana/terbang.Seperti hal-nya kota-kota di Jawa, Kota Juwana juga masih mempunyai tradisi atau adat-istiadat yang masih dilakukan setiap tahunnya. Tradisi tersebut diantaranya: Sedekah Laut, Sedekah Bumi, suronan, bersih desa, dan ruwat kota.

\section{Tradisi Acara Sedekah Laut}

Sedekah Laut merupakan tradisi masyarakat Juwana yang di laksanakan 1 tahun sekali, sepekan setelah lebaran sebagai wujud syukur kepada Tuhan atas hasil tangkapan nelayan dalam melaut. Sedekah Laut biasanya dilaksanakan di Desa Bendar ,Desa Bajomulyo, Desa Trimulyo, Desa Kedungpancing da Desa Bumirejo karena sebagian besar penduduknya berprofesi sebagai nelayan. Proses acara diawali dengan arak-arakan sesajen keliling desa kemudian menuju ke TPI (Tempat Pelelangan Ikan) Juwana. Setelah sampai di TPI, sesaji kemudian dibawa ke laut untuk di larung.

\section{Tradisi Acara Sedekah Bumi}


Seperti acara Sedekah Laut, tradisi Sedekah Bumi juga diselenggarakan secara turun menurun setiap 1 tahun sekali. Acara ini dilaksanakan setelah acara Sedekah Laut, sekitar bulan Apit (bulan jawa setelah bulan syawal) sebagai bentuk rasa bersyukur kepada Tuhan yang telah memberikan rezeki di bumi. Hampir semua desa di Juwana masih melaksanakan tradisi ini. Berbagai perlombaan kemasyarakatan serta pertunjukan seni, seperti ketoprak, tayuban, wayang kulit, karawitan maupun kesenian barongan ada di acara tersebut.

\section{c. Sumber Daya Alam}

Tidak hanya potensi Ekonomi dan potensi sosial budaya saja, potensi sumber daya alam Kota Juwana juga ada, diantaranya:

- Pulau Seprapat di Desa Bendar serta muaraSungai Silugonggo dengan panoramanya sebagai objek wisata bahari

- Area perhubungan laut sebagai media pelayaran untuk sumber daya jasa

- Kegiatan penangkapan ikan yang termasuk memiliki intensitas besar

- Kegiatan budidaya perikanan, khususnya tambak ikan bandeng dan udang

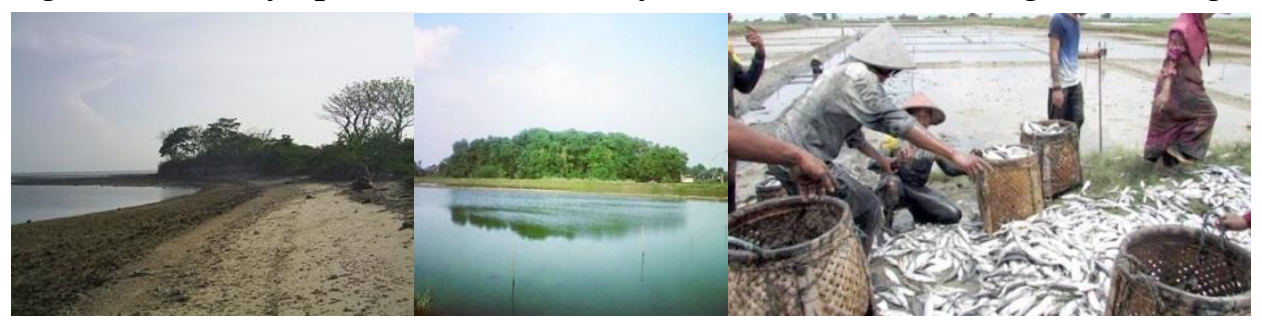

Gambar5. Pulau Seprapat (kiri \& tengah); Pasokan Ikan Bandeng Juwana (kanan) Sumber: (kiri\&tengah) http://www.teluklove.com(kanan) http://maritimindonesia.co.id/ (diakses Februari 2017)

\section{ELEMEN PEMBENTUK CITRA KOTA}

Analisis pembentuk citra kota dilakukan melalui investigasi kelima elemen pembentuk citra kota yaitu landmark, path, district, nodes, edge.

Tabel 2. Analisis Elemen Pembentuk Citra Kota

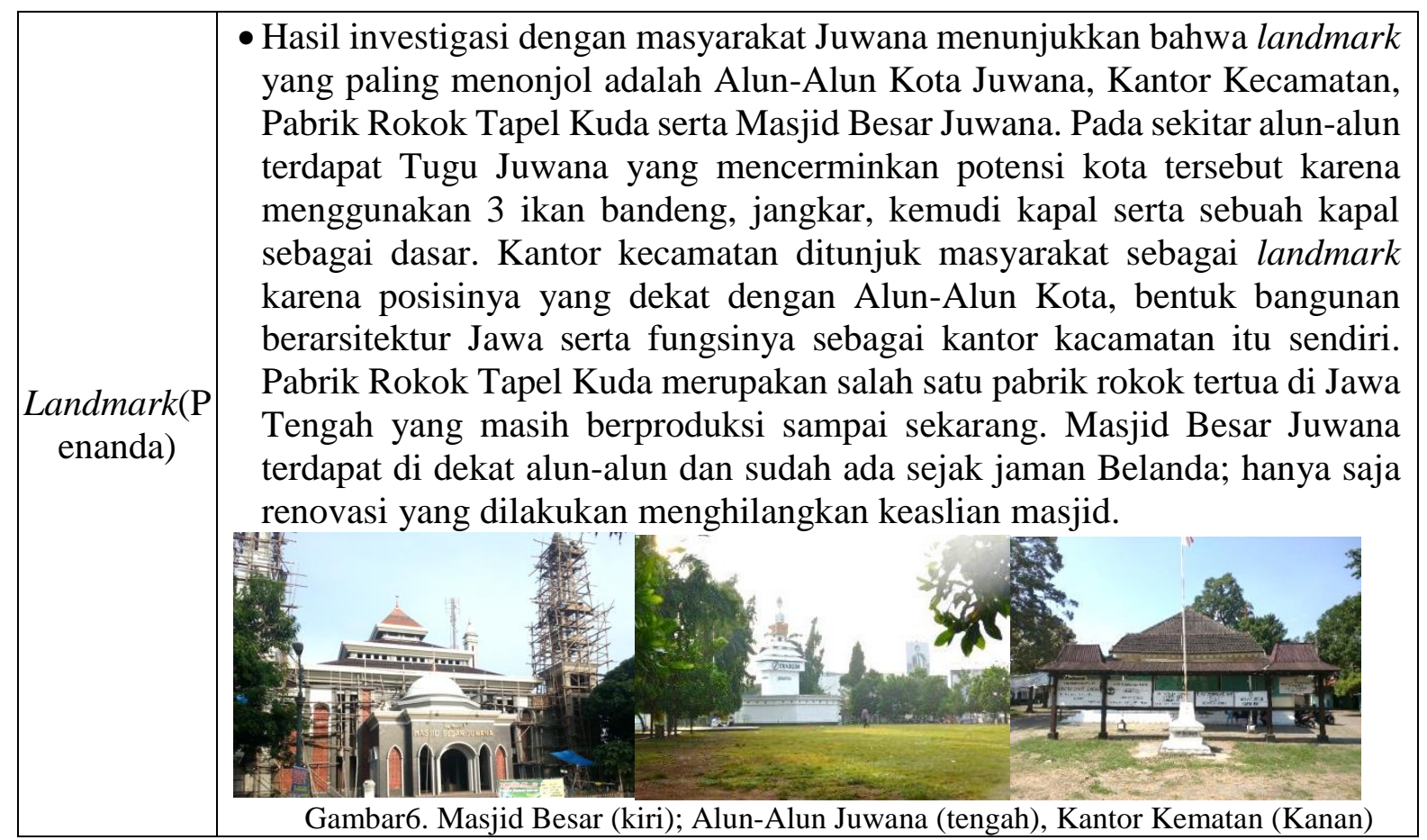




\begin{tabular}{|c|c|}
\hline & \\
\hline & $\begin{array}{l}\text { - Investigasi dilakukan dengan meminta masyarakat untuk memilih ruas jalan } \\
\text { yang paling mencirikan Kota Juwana. Berdasarkan hasil investigasi, ruas } \\
\text { Jalan Silugonggo merupakan ruas jalan yang berkesan dan paling menonjol, } \\
\text { dikarenakan banyak terdapat bangunan besar bersejarah berarsitektur } \\
\text { kolonial dan cina serta terdapat pabrik rokok Tapal Kuda. }\end{array}$ \\
\hline $\begin{array}{c}\text { district (kawa } \\
\text { san) }\end{array}$ & $\begin{array}{l}\text { - Hasil investigasi menunjukkan bahwa kawasan Kauman, Pajeksan dan } \\
\text { Kawasan Bakaran Kulon dan Wetan merupakan kawasan yang paling } \\
\text { menonjol di Juwana; hal tersebut tidak terlepas dari potensi yang dimiliki } \\
\text { Kauman, Pajeksan dan Bakaran. Pada Kawasan Kauman, terdapat banyak } \\
\text { bangunan bersejarah berarsitektur kolonial dan cina. Sedangkan pada } \\
\text { Bakaran Kulon dan Wetan terdapat banyak bangunan bersejarah } \\
\text { berarsitektur Jawa, serta potensi batik bakaran (lihat gambar 3) }\end{array}$ \\
\hline $\begin{array}{c}\text { Nodes } \\
\text { (persimpang } \\
\text { an) }\end{array}$ & $\begin{array}{l}\text { - Hasil investigasi menunjukkan bahwa nodes yang paling dominan di Kota } \\
\text { Juwana adalah simpul Jalan Silugonggo dan simpul jalan Raya Juwana-Pati. } \\
\text { Simpul Jalan Silugonggo dipilih karena letaknya yang berdekatan dengan } \\
\text { Sungai Silugonggo. Jalan Raya Juwana-Pati (Jln. Jend. Sudirman) } \\
\text { merupakan jalur penghubung antara Juwana dengan Pati. Pada } \\
\text { persimpangan jalan tersebut terdapat Tugu Bandeng Juwana yang juga } \\
\text { merupakan salah satu landmark di Kota Juwana.Terlebih lagi, kawasan di } \\
\text { sekitar jalan Silugonggo dan Jalan Jendral Sudirman tumbuh pesat karena } \\
\text { diapit oleh alun-alun Juwana, serta terdapat banyak bangunan dengan fungsi } \\
\text { pemerintahan dan perdagangan. }\end{array}$ \\
\hline
\end{tabular}




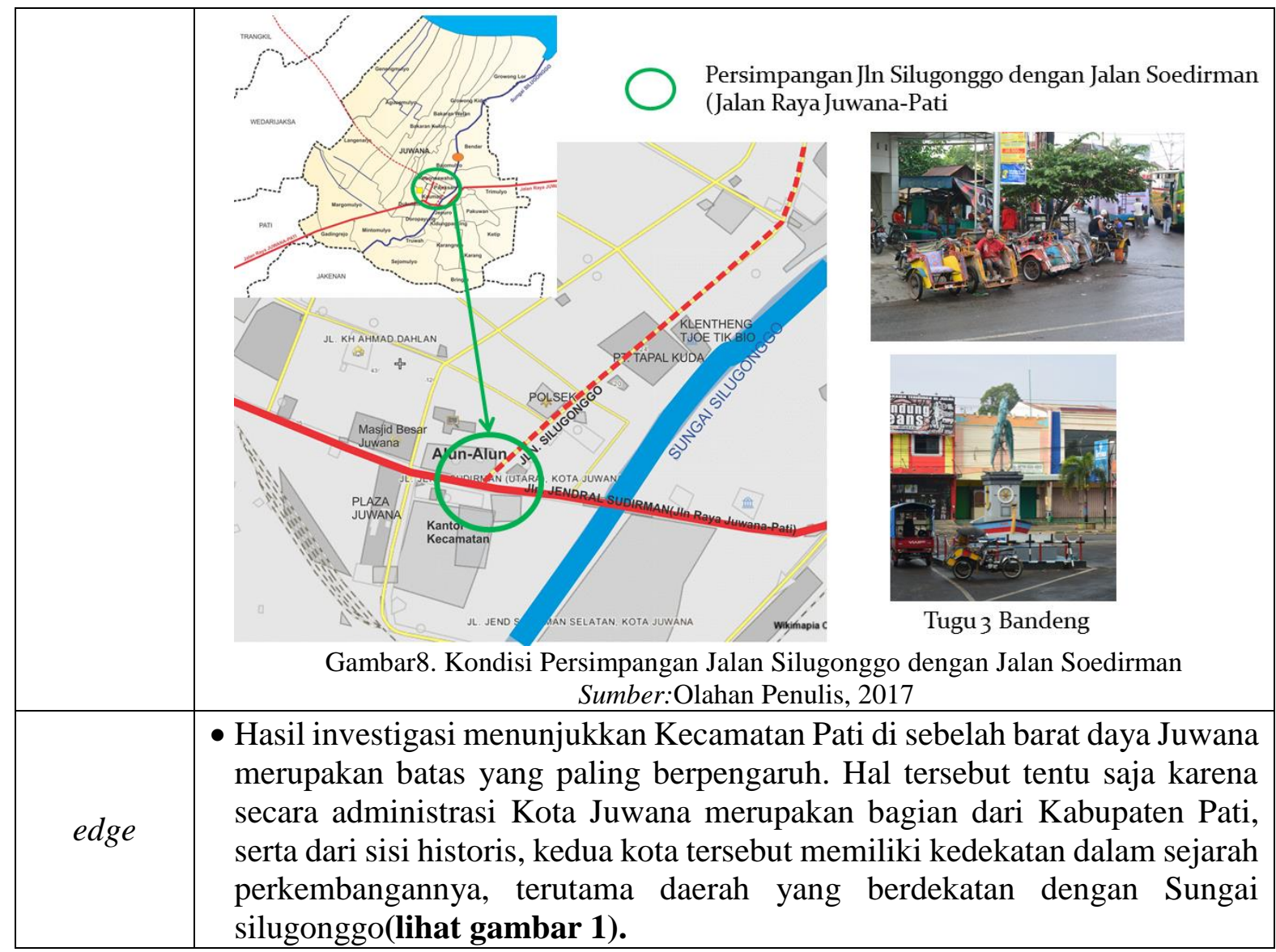

Sumber: Penulis, 2017

Dari beberapa potensi dan elemen pembentuk citra (landmark, path, district, nodes, egde) yang telah dianalisis diatas, citra kota Juwana sangat berpengaruh terhadap budaya khas atau heritage site yang sejak dulu sudah ada. Berdasarkan hal tersebut, Kota Juwana dapat menggunakan konsep Heritage City sebagai citra kota atau identitas kotanya. Konsep Heritage CityKota Juwana dapat dibagi menjadi 3 bagian yaitu Natural Heritage, Cultural Heritage sertaCultural-Landscape Heritage.

Tabel 3. Pembagian Konsep Heritage City

\begin{tabular}{|c|l|}
\hline $\begin{array}{c}\text { Natural } \\
\text { Heritage }\end{array}$ & $\begin{array}{l}\text { • Potensi alam yang dimiliki Juwana berupa objek wisata bahari di } \\
\text { Juwana adalah Pulau Seprapat di Desa Bendar dan Muara Sungai } \\
\text { Juwana dengan panorama alam pantai. }\end{array}$ \\
\hline \multirow{5}{*}{ Cultural } & $\begin{array}{l}\text { Potensi seni dan budaya seperti kesenian kethoprak, kesenian } \\
\text { kenthrung, kesenian laesan, dan kesenian rebana/terbang. } \\
\text { - Tradisi Kemasyarakatan, seperti sedekah laut, sedekah bumi, suronan, } \\
\text { bersih desa, dan ruwat kota. } \\
\text { - Kerajinan Kuningan dan Batik Bakaran Juwana. } \\
\text { - Industri Penangkapan Pengolahan ikan } \\
\text { - Peninggalan sejarah yang melekat pada Kota Juwana adalah bangunan } \\
\text { dengan arsitektur Belanda, Cina, dan Jawa. Perkembangannya dimulai } \\
\text { oleh kedatangan Belanda. }\end{array}$ \\
\hline
\end{tabular}




\begin{tabular}{|c|c|}
\hline $\begin{array}{c}\text { Cultural- } \\
\text { Landscape }\end{array}$ & $\begin{array}{l}\text { Potensi yang dimiliki Juwana dalam bidang ini adalah hamparan } \\
\text { tambak, hamparan kapal di pelabuhan Juwana, dan hamparan } \\
\text { Heritage }\end{array}$ \\
\hline
\end{tabular}

Sumber: Penulis, 2017

Kajian terhadap potensi Kota Juwana dapat juga diketahui bahwa Juwana merupakan kota pesisir bersejarah. Dalam perkembangannya, karakter spasial Kota Juwana kemungkinan akan mengalami pergeseran; sehingga perlu adanya strategi dalam menyikapi pergeseran serta untuk meningkatkan pariwisata Kota Juwana.

\section{KESIMPULAN DAN SARAN}

\section{Kesimpulan}

Berdasarkan hasil analisis dan pembahasan diatas, maka dapat disimpulkan :

1. Juwana memiliki berbagai potensi serta elemen pembentuk kota (landmark, path, district, nodes, egde) yang dapat dikembangkan untuk memperkuat citra kotanya sebagai Heritage City atau kota pesisir bersejarah.

2. Keragamanheritage site dan budaya khas yang ada di Kota Juwana, dapat dikembangkan dengan mengusung konsep Heritage City yang terdiri dari Natural Heritage, Cultural Heritage, dan Cultural-Landscape Heriage.

\section{Saran}

Struktur peruntukkan kawasan Juwana dapat diarahkan pada pengembangan kawasan wisata yang memanfaatkan karakteristik kawasan yang memiliki potensi unggulan sebagai pokok pengembangan kawasan. Strategi pengembangan pariwisata Kota Juwana dapat dilakukan melalui:

\section{Strategi Aktivitas Budaya}

Strategi ini meliputi: perlunya reimagining Kota Juwana yang kontekstual dengan karakter kota Juwana sebagai Heritage City; menjaga vitalitas kawasan melalui pemeliharaan keaslian bangunan kuno/bersejarah yang sudah ada; menjaga dan mempertahankan tradisi yang ada sebagai aktivitas budaya; menambah nilai jual wisata melalui peningkatan aktivitas budaya serta dengan menjaga living culture yang ada; memanfaatkan kekhasan arsitektur lokal secara komersial untuk menarik pengunjung.

\section{Strategi Ekonomi}

Strategi ini meliputi: pembinaan dan pengembangan terhadap ekonomi lokal yang ada; adanya agenda wisata terhadap event/acara di Kota Juwana kemudian dilakukan promosi dan sosialisai terhadap agenda tersebut; perlu adanya perbaikan dan peningkatan kearah profesional terhadap infrasturktur, fasilitas serta layanan wisata, meningkatkan konektivitas sektor transportasi publik sehingga dapat mempermudah pergerakan sektor wisata serta masyarakat Kota Juwana sendiri.

\section{Strategi Partisipasi Masyarakat}

Strategi ini meliputi: meningkatkan sense of belonging masyarakat Juwana akan pentingnya eksistensi kotanya terutama dari sisi sejarah, seni-budaya, lokasi, ekonomi serta tradisi 
masyarakat; melibatkan langsung masyarakat Kota Juwana dalam pemeliharaan dan pemanfaatan potensi-potensi di kotanya; adanya peran dari semua pihak (pemerintah, swasta dan masyarakat) dalam mengembangkan, mengelola serta memelihara potensi wisata Kota Juwana.

\section{REFERENSI}

Budihardjo, E. dan Sujarto, D. (2009). Kota berkelanjutan (Sustainable City). P.T. Alumni, Bandung.

Damanik, J., \& Weber, H. F. (2006). Perencanaan ekowisata: Dari teori ke aplikasi. Penerbit Andi, Yogyakarta.

Lynch, K. (1960). The Image of the City. Cambridge MA: MIT Press. USA.

Purwanto, E. (2014). Memahami citra kota teori, metode, dan penerapannya. Badan Penerbit Universitas Diponegoro, Semarang.

Southall, C, \& Peter, 2011. Heritage tourism. Dalam Robinson, P. Heitmann, S., Dieke, P. Research Theme /for Tourism. CAB International: Library of Congress Cataloging in Publication Data.

Strauss, A. L., and Corbin, J. (1998). Basics of qualitative research: Grounded theory procedures and techniques. 2nd. edition. Sage Publications, Newbury Park, CA.

Sudira, Putu. (2009). Studi mandiri grounded theory. Universitas Negeri Yogyakarta, Yogyakarta

Widiyanti, Baiq. (2015). Potensi pengembangan wisata sejarah budaya di kawasan kota tua ampenan, kota mataram, provinsi nusa tenggara barat. Seminar Ecologic City, Jakarta, 1819 September 2015, 1-9. 